\title{
Chelated Iron and Magnesium Boost Productivity and Anthocyanins Content in Calyces of Hibiscus sabdariffa $\mathrm{L}$.
}

\section{Ibrahim, O.H.M.}

Department of Ornamental Plants and Landscape Gardening, Faculty of Agriculture, Assiut University

E-mail: omer.ibrahim@aun.edu.eg

Received on: $12 / 3 / 2019$

Accepted for publication on: 19/3/2019

\section{Abstract:}

The present experiment was carried out to define the efficiency of foliar applications (3 times) with chelated magnesium (0, 200, 400 and $600 \mathrm{ppm})$ and iron $(0,150,300$ and $450 \mathrm{ppm})$ for improving growth, productivity and anthocyanins content in calyces of roselle. Results showed that calyces production and their contents of anthocyanins were significantly increased with increasing either $\mathrm{Mg}$ or Fe concentration. The combination of $\mathrm{Mg}$ at $600 \mathrm{ppm}$ and $\mathrm{Fe}$ at 450 was the most effective combined treatment in stimulating number of leaves and flowers, flower weight per plant, calyces dry weight per plant, seed dry weight per plant, weight of 1000 seeds and calyces content of anthocyanins. However, calyx fresh weight attained the highest values when the medium concentration of $\mathrm{Mg}$ (400 ppm) combined with Fe at the highest concentration (450 ppm) was employed.

Keywords: Roselle, foliar fertilization, pigments, vegetative growth

\section{Introduction}

Hibiscus sabdariffa L. is a summer annual crop that belongs to family Malvaceae and commonly known as roselle. It is indigenous to tropic Africa (Kirby, 1963) and widely cultivated in Upper Egypt governorates. Roselle is cultivated mainly for its fleshy red calyces (sepals) which is the commercial plant part. Calyces are famous for the preparation of hot or cold drinks and as a source of anthocyanins which is natural food coloring pigments (Diab, 1968). In addition to anthocyanins, calyces contain gossyperin and glycol side hibiscin, which have been reported to be hypotensive lowering blood pressure and stimulating intestinal peristalsis (Da-Costa-Rocha et al., 2014). Roselle seeds are also important as a source of fixed oil with antimicrobial activities (Hussin et al., 1991 and Fasoyiro et al., 2005). In folklore medicine, roselle is a remedy for cancer, abscesses, cough and fever in addition to many other diseases (Duke, 1979).

Despite the fact that roselle plant is adopted to a wide range of soil conditions, economic production requires high sepals yield and quality and therefore the soil should be well supplied with essential minerals (Adanlawo and Ajibade, 2006). Under the arid and semiarid conditions in Egypt, it has been recommended by several authors to supply nutrients through foliar application to allow quick compensation of nutrient deficiency particularly when it is difficult for roots to uptake necessary nutrients. Also, in foliar application lesser rate of nutrients are employed avoiding the toxicity of excessive elements and preventing nutrients fixation in case of soil fertilization (Malakouti 
and Tehrani, 1999 and El-Fouly et al., 2002).

Of the nutrients strongly related to pigmentation and many other yield traits, iron and magnesium are employed in the current investigation. Magnesium is involved in protein synthesis and associated with chlorophyll pigments, for it is an important cofactor of serval enzymes involved in photosynthetic carbon fixation and metabolism (Guo et al., 2016). Foliar applications of magnesium have also been reported to overcome the yellowing and browning of leaves associated with magnesium deficiency (Walker and Fisher, 1957) and may therefore also affect calyces color in roselle. Recently, Nissim-Levi et al. (2007) noticed an increase in anthocyanins accumulation in aster flowers due to the application of higher magnesium levels which probably help increase pigments stability. In this concern, several previous studies have reported the presence of stable complexes of anthocyanins with magnesium (Kondo et al., 1992, Takeda et al., 1994 and Takeda, 2006).

Elicitation of anthocyanin production in roselle and many other plant species has been recently reported due to the application of iron by Dahmardeh et al. (2017) who recorded a significant increase in anthocyanins content due to the elevated concentrations of foliar iron fertilization. Gomaa et al. (2018) also reported that $\mathrm{Fe}$ foliar spray increased the growth and yield characteristics including total anthocyanins content of roselle plants. Similar results were also demonstrated by Ghatas and Mohamed (2018) on Cymbopgon citruts. Iron is a metal components of various enzymes and plays an important role as a functional, structural, or regulatory cofactor. Therefore, it is important in photosynthesis, in enzyme systems and respiration of plants (Tariq et al., 2004 and Marschner, 2012). Although anthocyanins structure doesn't contain iron, enhancement in anthocyanin production has been reported by the addition of the alternative iron source FeEDDHA. This increase in anthocyanin content could be ascribed to the greater availability of iron or through iron's ability to inhibit anthocyanin degradation (Fang et al., 1999). The effects of $\mathrm{Fe}$ on the biosynthesis of anthocyanins starting with phenylalanine as a precursor, as well as the accumulation of individual anthocyanins have been little studied as stated by Shi et al. (2017).

Considering the role of both magnesium and iron in enhancing growth and anthocyanins content, the current investigation was initiated to clarify the response of roselle plants to the foliar application of $\mathrm{Fe}$ and/or magnesium at different concentrations.

\section{Materials and Methods}

The present study was carried out during the two successive seasons of 2016/2017 and 2017/2018 at the Floriculture Experimental Farm, Faculty of Agriculture, Assiut University, Egypt. The soil of the experimental field was analyzed according to the methods described by Jackson (1973) which revealed that the soil type was clayey loam and its properties include: $\mathrm{pH}$ 8.71, $\mathrm{EC}(\mathrm{dS} / \mathrm{m})$ 1.03 , organic matter $0.97 \%$, total $\mathrm{CaCO}_{3} 1.97 \%$, total $\mathrm{N} 0.70 \%$, total $\mathrm{P}$ $0.21 \%$ and total $\mathrm{K} 0.41 \%$. 
The experiment was 4 x 4 factorial laid out in a split-plot design with three replications. Magnesium $(\mathrm{Mg})$ and Iron $(\mathrm{Fe})$ employed in the current study were used as foliar sprays in the form of EDTA chelate (13\%) produced by Nature SA, Greece. Magnesium was used at 4 concentrations $(0$, 200, 400 and $600 \mathrm{ppm}$ ) which were assigned to the main-plots. The subplots comprehended iron at four concentrations $(0,150,300$ and 450 $\mathrm{ppm})$. The experimental site was prepared as recommended before sowing the seeds. Plot area was $2 \times 1.5 \mathrm{~m}$ comprising 3 rows. In mid-April, seeds were sown in holes at a distance of $30 \mathrm{~cm}$ in each row and then thinned after germination (one seedling/ hole). Foliar sprays of the two nutrient elements were applied three times starting one month after planting and repeated twice at one month interval for both seasons. Control plants were sprayed with distilled water. All agricultural practices were performed as recommended during both seasons.

At the end of the growing season, data were recorded on plant height, number of branches and leaves per plant, number and weight of flowers, calyces fresh and dry weights, seed dry weight and weight of 1000 seeds. Besides, total anthocyanin content was determined in airdried calyces according to the $\mathrm{pH}$ differential method described by Lee et al. (2005). The absorbance was recorded at 510 and $700 \mathrm{~nm}$ in two buffers; the first at $\mathrm{pH} 1.0$ (potassium chloride, $0.025 \mathrm{M}$ ) and the second at pH 4.5 (sodium acetate, $0.4 \mathrm{M}$ ). The concentration of anthocyanins was calculated as $\mathrm{mg}$ cyanidin 3- glucoside equivalents/g dry weight using the formula:

Total anthocyanin $(\mathrm{mg} / \mathrm{g} \mathrm{DW})=$ $(\mathrm{A} \times \mathrm{MW} \times \mathrm{DF} \times 1000) /(\square \times 1)$

Where $A=\left(A_{510 ~ n m}-A_{700 \mathrm{~nm}}\right)$ pH $1.0-\left(\mathrm{A}_{510 \mathrm{~nm}}-\mathrm{A}_{700 \mathrm{~nm}}\right) \mathrm{pH} 4.5$; MW (molecular weight) $=449.2$ $\mathrm{g} / \mathrm{mol}$; DF $=$ dilution factor; $1=\mathrm{cu}-$ vette path length in $\mathrm{cm} ; \varepsilon=26900$ $\mathrm{L} / \mathrm{mol} . \mathrm{cm}$ which is the molar extinction coefficient for cyanidin $3-O-\beta-\mathrm{D}-$ glucoside. $1000=$ factor to convert $g$ to $\mathrm{mg}$. The measurements were performed using a UV-visible spectrophotometer (Optizen Pop, Mecasys Korea).

Data were subjected to statistical analysis using "F" Test (Snedecor and Cochran, 1989) and L.S.D. value for comparison according to Steel and Torrie (1982). Statistical analysis was performed using Statistix 8.1 program.

\section{Results and Discussion \\ Vegetative growth}

Elevated $\mathrm{Mg}$ concentrations caused significant augmentation in plant height and leaf number as shown in Table 1. The highest $\mathrm{Mg}$ concentration $(600 \mathrm{ppm})$ resulted in significantly taller plants and higher leaf number than the other treatments or the control. Although $\mathrm{Mg}$ at 600 ppm was the most effective treatment in stimulating shoot elongation and leaf formation, it produced the least branch number. However, $\mathrm{Mg}$ at 200 ppm showed a pronounced increase in branch number during both seasons. The role of magnesium in enhancing vegetative growth has been previously demonstrated by Ibrahim et al. (2016a) on parsley plant. They reported significant effect of $\mathrm{Mg}$ foliar application on the vegetative 
growth parameters where the effect became more pronounced as the $\mathrm{Mg}$ concentration was increased. The results are in line with the findings of Upadhyay and Patra (2011). Similarly, Nakhumicha Muriithi et al. (2009) recorded an increase in tuberose leaf area and leaf dry weight in response to the application of $\mathrm{Mg}$. Abou El-Nour and Shaaban (2012) also detected a significant increase in wheat plant height in response to the foliar the application of magnesium sulphate at $5000 \mathrm{ppm}$. Other authors have emphasized the enhancement influence of $\mathrm{Mg}$ on number of branches and leaves such as Waskela et al. (2013) on guava and Venkataramana (2012) on black pepper.

The promotive effect of $\mathrm{Mg}$ on vegetative growth may be ascribed to its contribution in photosynthesis as a carrier of phosphorus and its role in nutrient uptake, sugar synthesis and starch translocation (Abou El-Nour and Shaaban, 2012 and Marschner, 2012).

Vegetative characteristics also showed significant enhancement in response to the increase in $\mathrm{Fe}$ concertation reaching the peak in plant height and branch number when the medium concertation (300 ppm) was sprayed. However, roselle plants sprayed with $\mathrm{Fe}$ at the highest concentration $(450 \mathrm{ppm})$ possessed more leaves than the other concentrations. In accordance with these results Ibrahim et al. (2016a) reported that foliar fertilization of parsley plants with $\mathrm{Fe}$ at different concentrations revealed significant effects on growth parameters. Increasing the concentration of Fe resulted in significantly better results. The role of iron in improving plant growth and quality was reported by Ibrahim et al. (2016b) who confirmed the significant improvement of safflower plant growth and productivity in response to the foliar application of iron at $300 \mathrm{ppm}$. Similar results were reported by Said-Al Ahl and Omer (2009) regarding the significant effect of the foliar application of iron at $200 \mathrm{ppm}$ on growth of coriander plants. Also, Ghatas and Mohamed (2018) and Gomaa et al. (2018) reported considerable enhancement in vegetative growth of the plants sprayed with micronutrients including Fe. 
Website: www.aun.edu.eg/faculty_agriculture/journals_issues_form.php E-mail: ajas@aun.edu.eg

Table 1. Effect of Fe and Mg concentrations on vegetative growth characters of roselle plant during 2016/2017 and 2017/2018 seasons.

\begin{tabular}{|c|c|c|c|c|c|c|c|}
\hline \multirow{2}{*}{$\begin{array}{c}\text { Mg } \\
(\mathrm{ppm})\end{array}$} & \multirow{2}{*}{$\begin{array}{c}\mathrm{Fe} \\
(\mathrm{ppm})\end{array}$} & \multicolumn{2}{|c|}{ Plant height (cm) } & \multicolumn{2}{|c|}{ Branch number/plant } & \multicolumn{2}{|c|}{ Leaf number/plant } \\
\hline & & $1^{\text {st }}$ season & $2^{\text {nd }}$ season & $1^{\text {st }}$ season & $2^{\text {nd }}$ season & $1^{\text {st }}$ season & $2^{\text {nd }}$ season \\
\hline \multirow{4}{*}{ Control } & Control & 101.85 & 104.28 & 3.22 & 3.28 & 123.95 & 124.65 \\
\hline & 150 & 121.54 & 124.50 & 3.46 & 3.15 & 168.50 & 170.83 \\
\hline & 300 & 125.00 & 125.83 & 4.25 & 4.29 & 181.50 & 182.83 \\
\hline & 450 & 122.50 & 123.40 & 3.48 & 3.54 & 184.12 & 186.71 \\
\hline Mean & & 117.72 & 119.50 & 3.60 & 3.56 & 164.52 & 166.26 \\
\hline \multirow{4}{*}{200} & Control & 105.30 & 106.77 & 4.00 & 4.07 & 147.15 & 149.72 \\
\hline & 150 & 113.00 & 113.67 & 4.45 & 4.52 & 176.50 & 178.83 \\
\hline & 300 & 124.06 & 125.69 & 5.55 & 5.63 & 202.30 & 207.43 \\
\hline & 450 & 128.42 & 129.22 & 5.50 & 5.59 & 209.50 & 211.83 \\
\hline Mean & & 117.69 & 118.84 & 4.88 & 4.95 & 183.86 & 186.95 \\
\hline \multirow{4}{*}{400} & Control & 115.77 & 115.33 & 4.39 & 4.41 & 149.50 & 151.17 \\
\hline & 150 & 123.92 & 126.25 & 3.75 & 3.58 & 184.75 & 186.92 \\
\hline & 300 & 132.40 & 134.47 & 4.65 & 4.64 & 187.49 & 188.83 \\
\hline & 450 & 128.60 & 129.53 & 4.25 & 4.27 & 216.60 & 217.53 \\
\hline Mean & & 125.17 & 126.40 & 4.26 & 4.23 & 184.58 & 186.11 \\
\hline \multirow{4}{*}{600} & Control & 118.00 & 119.33 & 3.15 & 3.28 & 152.50 & 154.17 \\
\hline & 150 & 129.00 & 130.67 & 3.49 & 3.60 & 238.35 & 239.45 \\
\hline & 300 & 129.50 & 131.50 & 3.50 & 3.60 & 253.00 & 254.67 \\
\hline & 450 & 131.25 & 132.58 & 4.42 & 4.51 & 299.00 & 300.67 \\
\hline Mean & & 126.94 & 128.52 & 3.64 & 3.75 & 235.71 & 237.24 \\
\hline \multirow{4}{*}{$\begin{array}{l}\text { Means of } \\
\text { Fe }\end{array}$} & Control & 110.23 & 111.43 & 3.69 & 3.76 & 143.28 & 144.93 \\
\hline & 150 & 121.86 & 123.77 & 3.79 & 3.71 & 192.03 & 194.01 \\
\hline & 300 & 127.74 & 129.37 & 4.49 & 4.54 & 206.07 & 208.44 \\
\hline & 450 & 127.69 & 128.68 & 4.41 & 4.48 & 227.31 & 229.19 \\
\hline \multirow[t]{3}{*}{\begin{tabular}{|l} 
LSD 0.05 \\
\end{tabular}} & $\mathrm{Mg}$ & 0.62 & 2.02 & 0.93 & 0.36 & 4.16 & 3.25 \\
\hline & $\mathrm{Fe}$ & 1.41 & 2.21 & 0.60 & 0.16 & 5.30 & 4.88 \\
\hline & Interaction & 2.82 & 4.41 & NS* & 0.32 & 10.60 & 9.75 \\
\hline
\end{tabular}

* NS denotes non-significant differences using ANOVA

To understand the role iron in augmenting plant vegetative growth, it is important to take into consideration that iron is a metal component of various enzymes in addition to being a cofactor in many biological functions including photosynthesis, respiration and in enzyme systems of plants (Tariq et al., 2004 and Marschner, 2012). This beneficial effect might be due to interaction of nutrients and their role in the synthesis of IAA, metabolism of auxin and formation of chlorophyll synthesis as reported by Rathore and Tomar (1990).

When both elements were combined together, they significantly boosted vegetative growth where the combination between the highest concentrations of both $\mathrm{Mg}$ and $\mathrm{Fe}$ produced the tallest plants with the highest number of leaves. Whereas, number of branches exhibited the best behavior in those plants sprayed with the lowest $\mathrm{Mg}$ concentration combined with $\mathrm{Fe}$ at the medium or the highest concentration. In accordance with these results, Ibrahim et al. (2016a) proved that the best interaction between $\mathrm{Fe}$ and $\mathrm{Mg}$ was found in parsley plants sprayed with $\mathrm{Fe}$ at 200 or $400 \mathrm{ppm}$ combined with $\mathrm{Mg}$ at 200 $\mathrm{ppm}$. The authors ascribed the promotive effects of both $\mathrm{Mg}$ and $\mathrm{Fe}$ to the fact that plants receiving $\mathrm{Fe}$ and/or Mg might have been helped in 
terms of vigorous root growth, formation of chlorophyll, resulting in higher photosynthesis and protein which resulted in better growth.

\section{Flowering characteristics}

To elucidate the response of roselle plants to the foliar application of $\mathrm{Mg}$ and $\mathrm{Fe}$, data on flowering characteristics are presented in Tables 2 and 3. A positive relationship was observed between the raise in $\mathrm{Mg}$ concentration and the incident increment in flowering characteristics. Flower number and weight showed higher values when $\mathrm{Mg}$ was applied at the highest concentration (600 ppm), meanwhile the medium concertation (400 ppm) was superior in case of fresh and dry weights of calyces. Similar results were obtained by Nakhumicha Muriithi et al. (2009) on tuberose and Harris et al. (2018) on chilli, who recorded enhancement effects on flower characteristics in response to the application of $\mathrm{Mg}$.

Flower number and weight showed considerable responses to $\mathrm{Mg}$ foliar application in a similar pattern of the vegetative characteristics implying the strong influence of the vegetative growth vigor on the flowering performance. Harris et al. (2018) suggested an explanation based on the assumption that the higher number of flowers might be due to the adequate supply of $\mathrm{Mg}$ which results in increased leaf formation that leads to increase in photosynthesis activity, consequently more photosynthetic products leading to more carbohydrate accumulation which closely correlated with dense flowers and their pigments content. Street and Opik (1976) concluded that leaf number per plant affects the profusion of flowering and the processes involved in the transformation of a vegetative apex into a reproductive apex and these factors control the development of functional flowers. Marschner (2012) demonstrated that $\mathrm{Mg}$ plays two very essential roles in the plant which are found in the important processes of photosynthesis and carbohydrate metabolism. The role of $\mathrm{Mg}$ at certain concertation is closely correlated with chlorophyll synthesis, it is a constituent of chlorophyll molecule and without it, photosynthesis would not occur. Magnesium application exerted promotive influence on plant height and the production of branches that in turn increases the number of nodes and then the number of flowers. The promotive effect of $\mathrm{Mg}$ on vegetative growth may be ascribed to its role in nutrient uptake, sugar synthesis and starch translocation (Marschner, 2012). 
Website: www.aun.edu.eg/faculty_agriculture/journals_issues_form.php E-mail:ajas@aun.edu.eg

Table 2. Effect of Fe and Mg concentrations on flower characters of roselle during 2016/2017 and 2017/2018 seasons.

\begin{tabular}{|c|c|c|c|c|c|c|c|}
\hline \multirow{2}{*}{$\begin{array}{c}\text { Mg } \\
(\mathbf{p p m})\end{array}$} & \multirow{2}{*}{$\begin{array}{c}\mathrm{Fe} \\
(\mathrm{ppm})\end{array}$} & \multicolumn{2}{|c|}{ Flower number/plant } & \multicolumn{2}{|c|}{ Flower weight (g)/plant } & \multicolumn{2}{|c|}{ Calyx FW* (g)/plant } \\
\hline & & $1^{\text {st }}$ season & $2^{\text {nd }}$ season & $1^{\text {st }}$ season & $2^{\text {nd }}$ season & $1^{\text {st }}$ season & $2^{\text {nd }}$ season \\
\hline \multirow{4}{*}{ Control } & Control & 21.67 & 22.89 & 206.11 & 208.37 & 84.28 & 86.02 \\
\hline & 150 & 36.00 & 36.50 & 244.75 & 248.68 & 124.53 & 125.36 \\
\hline & 300 & 39.10 & 39.73 & 268.00 & 270.67 & 130.50 & 135.83 \\
\hline & 450 & 58.27 & 41.38 & 282.88 & 284.22 & 138.21 & 145.33 \\
\hline Mean & & 38.76 & 35.12 & 250.44 & 252.98 & 119.38 & 123.14 \\
\hline \multirow{4}{*}{200} & Control & 36.80 & 37.41 & 213.25 & 216.08 & 104.50 & 107.17 \\
\hline & 150 & 48.30 & 48.10 & 261.25 & 262.42 & 137.50 & 140.50 \\
\hline & 300 & 49.17 & 43.35 & 287.43 & 292.10 & 150.49 & 155.33 \\
\hline & 450 & 55.59 & 42.59 & 348.80 & 350.36 & 155.70 & 158.33 \\
\hline Mean & & 47.46 & 42.86 & 277.68 & 280.24 & 137.05 & 140.33 \\
\hline \multirow{4}{*}{400} & Control & 37.25 & 38.08 & 216.95 & 218.98 & 106.65 & 108.55 \\
\hline & 150 & 50.66 & 51.56 & 251.30 & 257.10 & 149.25 & 152.08 \\
\hline & 300 & 53.65 & 54.35 & 313.45 & 321.15 & 160.90 & 166.97 \\
\hline & 450 & 50.05 & 51.28 & 354.95 & 359.98 & 164.50 & 168.83 \\
\hline Mean & & 47.90 & 48.82 & 284.16 & 289.30 & 145.33 & 149.11 \\
\hline \multirow{4}{*}{600} & Control & 40.50 & 41.17 & 220.95 & 226.98 & 104.90 & 106.63 \\
\hline & 150 & 52.45 & 52.88 & 280.00 & 283.33 & 153.29 & 160.10 \\
\hline & 300 & 52.85 & 52.95 & 326.25 & 332.08 & 151.85 & 157.28 \\
\hline & 450 & 58.45 & 58.48 & 360.50 & 363.50 & 152.45 & 157.82 \\
\hline Mean & & 51.06 & 51.37 & 296.93 & 301.48 & 140.62 & 145.46 \\
\hline \multirow{4}{*}{$\begin{array}{l}\text { Means of } \\
\mathrm{Fe}\end{array}$} & Control & 34.05 & 34.89 & 214.32 & 217.61 & 100.08 & 102.09 \\
\hline & 150 & 46.85 & 47.26 & 259.33 & 262.88 & 141.14 & 144.51 \\
\hline & 300 & 48.69 & 47.60 & 298.78 & 304.00 & 148.43 & 153.85 \\
\hline & 450 & 55.59 & 48.43 & 336.78 & 339.52 & 152.71 & 157.58 \\
\hline \multirow[t]{3}{*}{ LSD 0.05} & $\mathrm{Mg}$ & 1.57 & 2.21 & 3.66 & 6.28 & 3.80 & 2.90 \\
\hline & $\mathrm{Fe}$ & 0.74 & 1.21 & 4.49 & 4.10 & 2.97 & 2.94 \\
\hline & Interaction & 1.49 & 2.43 & 8.97 & 8.21 & 5.93 & 5.87 \\
\hline
\end{tabular}

* FW denotes fresh weight

The same trend aforementioned for $\mathrm{Mg}$ was noticed when Fe was applied where flowering characteristics showed significant gradual increase as the concertation of $\mathrm{Fe}$ was raised. Spraying roselle plants with the highest concertation of Fe (450 ppm) led to the best results regarding number and weight of flowers as well as fresh and dry weights of calyces (Tables 2 and 3 ). In case of calyx dry weight, the medium Fe concentration (300 ppm) showed non-significant differences with the highest concentration during the second season. These results are consistent with the findings of Dahmardeh et al. (2017) and Gomaa et al. (2018) who recorded significant increase in fresh and dry weights of roselle calyces in response to the iron fertilization. As previously mentioned by Tariq et al. (2004) and Marschner (2012), iron has an important role in photosynthesis and in enzyme systems and respiration of plants affecting all plant growth stages including the flowering stage.

The interaction between $\mathrm{Mg}$ and Fe concentrations exerted significant effects on flowering characteristics. The highest concentrations of both elements combined together resulted 
in the highest values regarding number and weight of flowers as well as calyx dry weight. However, calyx fresh weight attained the highest values when sprayed with the medium concentration of $\mathrm{Mg}$ combined with
Fe at the highest concentration. It was also noticed that the same combined treatment was competitive and showed high values in fresh weight of flowers and calyces.

Table 3. Effect of $\mathrm{Fe}$ and Mg concentrations on dry weight of calyces and seed characteristics of roselle plant during $2016 / 2017$ and $2017 / 2018$ seasons.

\begin{tabular}{|c|c|c|c|c|c|c|c|}
\hline \multirow{2}{*}{$\begin{array}{c}\text { Mg } \\
(\text { ppm) }\end{array}$} & \multirow{2}{*}{$\underset{(\mathbf{p p m})}{\mathrm{Fe}}$} & \multicolumn{2}{|c|}{ Calyx DW* (g)/plant } & \multicolumn{2}{|c|}{ Seed DW (g)/plant } & \multicolumn{2}{|c|}{$\begin{array}{c}\text { Weight of } 1000 \text { seeds } \\
(\mathrm{g})\end{array}$} \\
\hline & & $1^{\text {st }}$ season & $2^{\text {nd }}$ season & $1^{\text {st }}$ season & $2^{\text {nd }}$ season & $1^{\text {st }}$ season & $2^{\text {nd }}$ season \\
\hline \multirow{4}{*}{ Control } & Control & 15.79 & 17.97 & 3.33 & 3.51 & 10.83 & 10.34 \\
\hline & 150 & 17.13 & 18.02 & 4.40 & 4.61 & 13.65 & 13.82 \\
\hline & 300 & 17.73 & 17.20 & 7.73 & 7.72 & 13.95 & 14.32 \\
\hline & 450 & 17.53 & 15.73 & 7.77 & 8.01 & 15.56 & 15.85 \\
\hline Mean & & 17.05 & 17.23 & 5.81 & 5.96 & 13.50 & 13.58 \\
\hline \multirow{4}{*}{200} & Control & 17.30 & 17.93 & 3.49 & 3.72 & 13.94 & 14.81 \\
\hline & 150 & 21.46 & 21.29 & 4.41 & 4.81 & 13.97 & 14.52 \\
\hline & 300 & 19.40 & 20.47 & 7.13 & 7.34 & 15.06 & 15.45 \\
\hline & 450 & 21.81 & 22.04 & 8.03 & 7.94 & 18.12 & 18.04 \\
\hline Mean & & 19.99 & 20.43 & 5.76 & 5.95 & 15.27 & 15.71 \\
\hline \multirow{4}{*}{400} & Control & 21.07 & 21.39 & 3.43 & 3.38 & 14.48 & 13.49 \\
\hline & 150 & 22.35 & 23.12 & 3.95 & 3.78 & 16.05 & 15.35 \\
\hline & 300 & 22.80 & 23.43 & 7.37 & 7.12 & 16.87 & 16.62 \\
\hline & 450 & 24.30 & 24.43 & 8.50 & 8.17 & 17.41 & 18.47 \\
\hline Mean & & 22.63 & 23.09 & 5.81 & 5.61 & 16.20 & 15.98 \\
\hline \multirow{4}{*}{600} & Control & 18.40 & 19.97 & 4.22 & 4.07 & 15.08 & 15.36 \\
\hline & 150 & 19.40 & 20.47 & 4.96 & 4.32 & 15.05 & 14.68 \\
\hline & 300 & 24.30 & 25.43 & 9.00 & 7.33 & 16.63 & 14.88 \\
\hline & 450 & 22.65 & 23.88 & 10.50 & 9.83 & 22.11 & 22.04 \\
\hline Mean & & 21.19 & 22.44 & 7.17 & 6.39 & 17.22 & 16.74 \\
\hline \multirow{4}{*}{$\begin{array}{l}\text { Means of } \\
\mathrm{Fe}\end{array}$} & Control & 18.14 & 19.31 & 3.62 & 3.67 & 13.58 & 13.50 \\
\hline & 150 & 20.08 & 20.72 & 4.43 & 4.38 & 14.68 & 14.59 \\
\hline & 300 & 21.06 & 21.63 & 7.81 & 7.38 & 15.63 & 15.32 \\
\hline & 450 & 21.57 & 21.52 & 8.70 & 8.49 & 18.30 & 18.60 \\
\hline \multirow[t]{3}{*}{ LSD 0.05} & $\mathrm{Mg}$ & 0.65 & 1.05 & 0.07 & NS** & 0.44 & 0.96 \\
\hline & $\mathrm{Fe}$ & 0.32 & 0.59 & 0.07 & 0.30 & 0.29 & 0.52 \\
\hline & Interaction & 0.64 & 118 & 0.13 & 0.59 & 0.59 & 1.03 \\
\hline
\end{tabular}

* NS denotes non-significant differences using ANOVA, ** DW denotes dry weight.

\section{Seed weight}

Considering the importance of roselle seeds possessing valued active components for pharmacological uses, dry weight of seeds and weight of 1000 seeds were recorded and the data are presented in Table 3. A gradual increase in dry weight of seeds and weight of 1000 seeds was noticed with increasing $\mathrm{Mg}$ concen- tration. Thus, the concertation of 600 ppm exhibited superior results comparing to the other concentrations or the control. These results agree with those revealed by Harris et al. (2018) who demonstrated that $\mathrm{Mg}$ played an important role in increasing the number of fruits in chilli plants. Also, Babaeian et al. (2012) on barley and Venkataramana (2012) on black pep- 
per proved the contribution of $\mathrm{Mg}$ in increasing yield.

The strong and direct relationship between the plant performance during both the vegetative and the flowering stages with seed yield is clear. As previously mentioned, foliar application of $\mathrm{Mg}$ at elevated concentrations resulted in consistent enhancement in vegetative growth and flowering of roselle which led ultimately to high seed yield. This interpretation was suggested as well by Harris et al. (2018) who revealed that the increase in the number of fruits might be due to the contribution of $\mathrm{MgSO}_{4}$ in improving vegetative growth and flowering. A similar suggestion was also mentioned by Ram and Bose (2000) indicating that adequate quantity of micronutrients at the correct time is needed for greater growth which in turn leads to higher yield. Hence, the higher yield was attributed to the better flowering and higher fruit-set.

The effect of iron on both traits was also significant. When Fe concertation was increased, a consistent increment in dry weight of seeds and weight of 1000 seeds were observed. The highest values of both traits were recorded in the plants sprayed with $\mathrm{Fe}$ at the highest concentration (450 ppm) in both seasons (Table 3). Increment in seed weight due to the foliar application of iron has been previously pointed out by Gomaa et al. (2018) who reported a remarkable effect of Fe fertilization on seed yield per roselle plant. Similar results were obtained by Goos and Johnson (2000) on soybean. Likewise, Goos et al. (2004) and Wiersma (2005) recommended the application of FeEDDHA at high rates in order to correct chlorosis and increase seed yield.

The role of iron in the growth and reproduction of the plants is well documented (Tato et al., 2013) including its important role in cell metabolism. Therefore, Fe deficiency causes malfunction in several important physiological processes which adversely affects plant growth and leaf chlorosis reducing photosynthetic efficiency. Moreover, Fe deficiency influences root, shoot, and leaf growth and decreases fruit yield (Bertamini and Nedunchezhian, 2005, Álvarez-Fernández et al., 2011 and Tato et al., 2013).

Data presented in Table 3 also indicate that the combined treatments between $\mathrm{Mg}$ and $\mathrm{Fe}$ concentrations significantly varied in terms of dry weight of seeds and weight of 1000 seeds. The combination between the highest concentrations of both elements produced the best results in both traits.

\section{Total anthocyanins content}

One of the most important traits strongly affects the quality and therefore the price of roselle calyces is their content of anthocyanins. Data illustrated in Figs 1 exhibit significant improvements in anthocyanins content due to the foliar application of magnesium comparing to the control. In comparison with low $\mathrm{Mg}$ concentration, both the medium and the highest concentrations (400 and 600 ppm, respectively) exerted better results without significant differences between them in both seasons. Nissim-Levi et al. (2007) noticed an increase in anthocyanin accumulation in aster flowers due to higher magnesium levels. They attributed these re- 
sults to the role of magnesium application in increasing stability of plant pigments. In this concern, several previous studies have reported the presence of stable complexes of anthocyanins with magnesium (Kondo et al., 1992, Takeda et al., 1994 and Takeda, 2006). Nissim-Levi et al. (2007) tested the effect of $\mathrm{Mg}\left(\mathrm{NO}_{3}\right)_{2}$ treatment on a variety of plants and pigmented plant organs and have shown that the effect on pigmentation is broad. Shaked-Sachray et al., (2002) recorded an increase in anthocyanin concentration of aster flowers treated with magnesium On the other hand, Nakhumicha Muriithi et al. (2009) disclaimed the increased accumulation of $\mathrm{Mg}$ in tuberose tissues in response to supplying magnesium, and may not lead to accumulation of anthocyanins in the florets.

Due to the nature of anthocyanins owing enormous variation in location, timing, and inducibility, it is tricky to generate a unified explanation for the presence of these pig- ments (Hatier and Gould, 2009). To find out an acceptable explanation for the increment of anthocyanins content in response to the high concentrations of $\mathrm{Mg}$, we should take into account the previously discussed vegetative, flowering and seed yield traits. All these characteristics positively responded to the raise in $\mathrm{Mg}$ concentration which is reasonably justifiable in view of the importance of magnesium to plants for protein synthesis and chlorophyll pigments, acting mainly as a cofactor of several enzymes required for photosynthetic carbon fixation and metabolism (Guo et al., 2016). Anthocyaninmagnesium complexes, if formed, may increase the half-life time of the pigments, and/or inhibit their catabolism, and accordingly improve flower pigmentation (Shaul et al., 1999). In the same context, Nissim-Levi et al. (2007) hypothesized that the effect of $\mathrm{Mg}$ on pigmentation is due to the direct accumulation of $\mathrm{Mg}^{2+}$ ions in the colored plant organs.

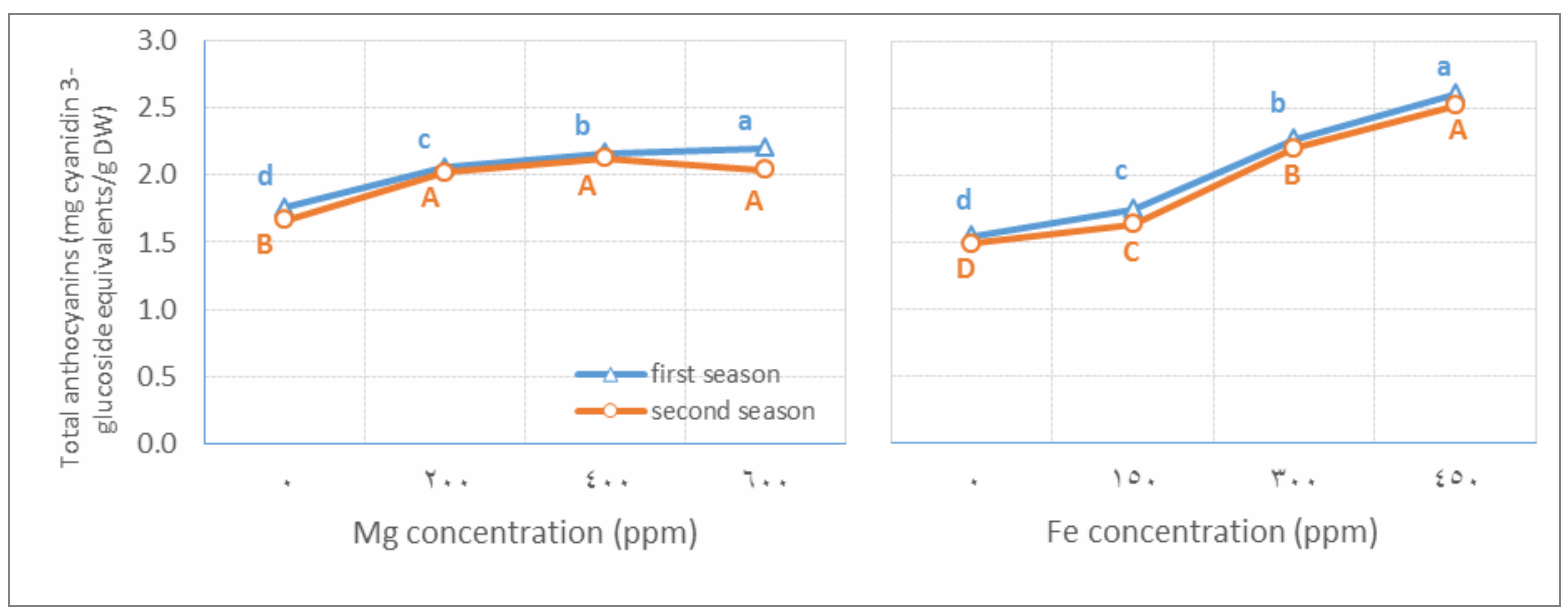

Fig. 1. The variations in total anthocyanins content in calyces of roselle plants under the foliar applications with Mg or Fe at different concentrations during 2016/2017 and 2017/2018 seasons. Different letters indicate significant differences using LSD at $p \leq 0.05$, small and capital letters are assigned for first and second seasons, respectively. 
The raise in iron concentration led to a consistent increase in calyx content of anthocyanins as the best results were attained when the highest Fe concentration $(450 \mathrm{ppm})$ was applied (Fig. 1). Elicitation of anthocyanin production in roselle and many other plant species has been reported due to the application of iron by several authors such as Dahmardeh et al. (2017) who recorded significant increase in anthocyanins content due to the elevated concentrations of foliar iron fertilization. Gomaa et al. (2018) also reported that foliar spray of iron increased the growth and yield characteristics including total anthocyanins content of roselle plants especially highest concentration in both seasons. Similar results were also demonstrated by Ghatas and Mohamed (2018) on Cymbopgon citruts.

Effect of iron on anthocyanins content is consistent with that on the vegetative, flowering and seed yield characteristics. Being a metal components of various enzymes or as functional, structural, or regulatory cofac- tors, Fe is important in photosynthesis and in enzyme systems and respiration of plants (Tariq et al., 2004 and Marschner, 2012). Although anthocyanins structure doesn't contain iron, enhancement in anthocyanin production has been reported by the addition of the alternative iron source FeEDDHA. This could be interpreted based on the greater availability of iron in a high light environment or through iron's ability to inhibit anthocyanin degradation (Fang et al. 1999). The effects of $\mathrm{Fe}$ on the biosynthesis of anthocyanins starting with phenylalanine as a precursor as well as the accumulation of individual anthocyanins have been little studied as stated by Shi et al. (2017).

Statistically, there were significant differences among the combined treatments between $\mathrm{Mg}$ and $\mathrm{Fe}$ at various concentrations in terms of anthocyanins content as illustrated in Fig 2. The combination between the highest $\mathrm{Fe}$ concertation and any of the three concentrations assigned for $\mathrm{Mg}$ showed significant superiority over the other treatments.

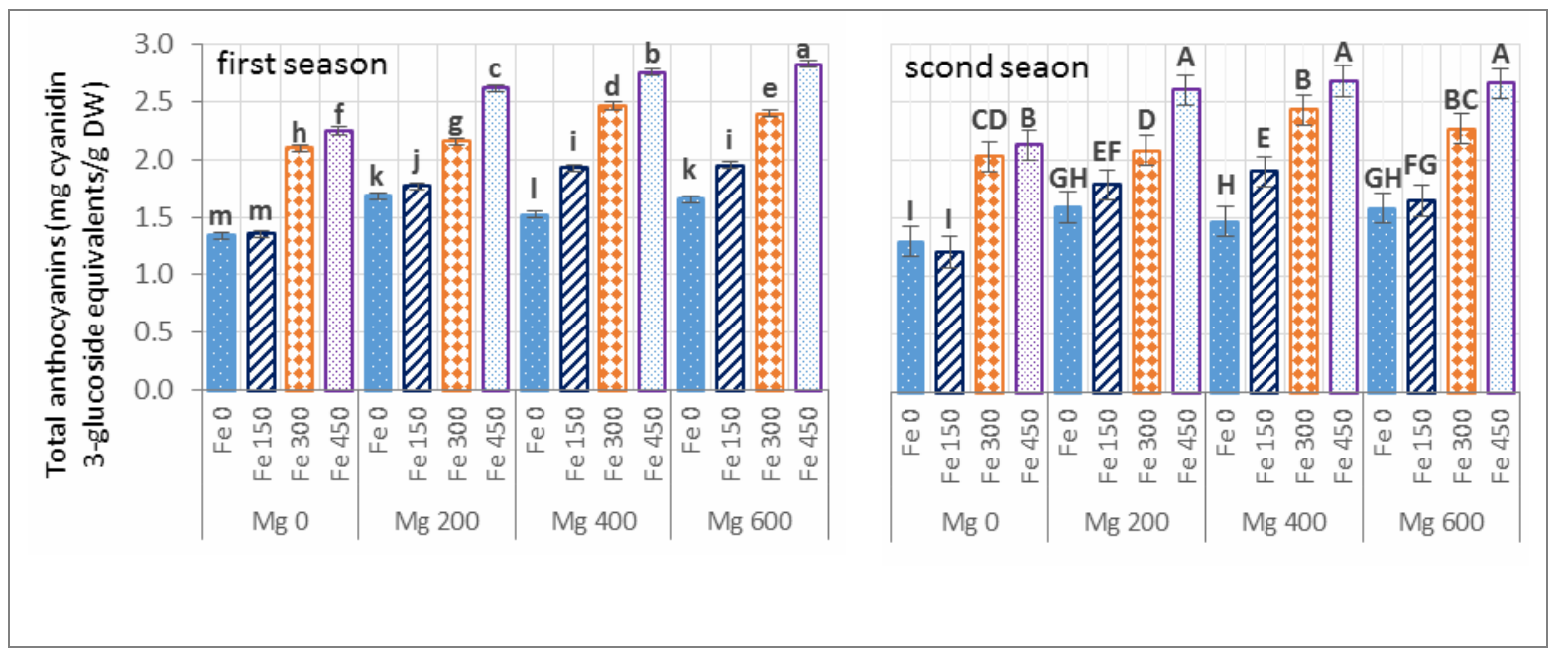

Fig. 2. The variations in total anthocyanins content in calyces of roselle plants in response to the combined treatments between different concentrations of $\mathrm{Mg}$ and Fe foliar applications during 2016/2017 and $2017 / 2018$ seasons. Vertical bars above mean denote LSD values $(p \leq 0.05)$, Different small and capital letters indicate significant differences in the first and second seasons, respectively. 


\section{Conclusions}

Despite the close relation between anthocyanin concentration with the $\mathrm{Mg}$ application and also the roles of $\mathrm{Mg}$ in plant metabolism encouraging in one way or another the accumulation of these pigments, there has been limited number of studies addressing the significance of $\mathrm{Mg}$ for the quality of roselle plant comparing to other major nutrients. Hence, the results revealed by the current study is considered important which indicated that improvement of roselle growth and productivity as well as calyces content of anthocyanins is attainable by the foliar application of $\mathrm{Mg}$ at $600 \mathrm{ppm}$ combined with $\mathrm{Fe}$ at $450 \mathrm{ppm}$.

\section{References}

Abou El-Nour, E.A.A., and Shaaban, M.M. (2012). Response of wheat plants to magnesium sulphate fertilization. Amer. J. Plant Nutr. Fert. Technol., 2: 56-63.

Adanlawo, I.G. and Ajibade, V.A. (2006). Nutritive value of the two varieties of roselle (Hibiscus sabdariffa) calyces soaked with wood ash. Pak. J. Nutr., 5: 555- 557.

Álvarez-Fernández, A., Melgar, J.C., Abadía, J. and Abadía, A. (2011). Effects of moderate and severe iron deficiency chlorosis on fruit yield, appearance and composition in pear (Pyrus communis L.) and peach (Prunus persica L. Batsch). Environ. Exp. Bot., 71: 280-286.

Babaeian, M., Esmaeilian, Y., Tavassoli, A. and Asgharzade, A. (2012). Efficacy of different iron, zinc and magnesium fertilizers on yield and yield components of barley. Afri. J. Microbiol. Res., 6(28): 57545756.

Bertamini, M. and Nedunchezhian, N. (2005). Grapevine growth and physiological responses to iron de- ficiency. J. Plant Nutr., 28: 737749.

Da-Costa-Rocha, I., Bonnlaender, B., Sievers, H., Pischel, I. and Heinrich, M. (2014). Hibiscus sabdariffa L. - a phytochemical and pharmacological review. Food Chem., 165: 424-443.

Dahmardeh, M, Khammari, I and Abdollahi,V.M(2017). Evalu ation of yield and yield components of borage (Borago officinalis) in intercropping with roselle (Hibiscus sabdariffa) foliar application of iron. M.Sc. Thesis, Zabol Univ., Iran.

Diab, M.A. (1968). The chemical Composition of Hibiscus sabdariffa, L. M.Sc. Thesis, Fac. Agric., Cairo Univ.

Duke, I.A. (1979). Ecosys rematic data on economic plants. Ouart. J. Crude Drug. Res., 17(3-4):91-110.

El-Fouly, M.M., Mobarak, Z.M. and Salama, Z.A. (2002). Micronutrient foliar application increases salt tolerance of tomato seedlings. Proc. Symp. Techniques to Control Salination for Horticultural Productivity. Acta Hort., 573: 377385.

Fang, Y., Smith, M.A.L. and Pépin, M.F. (1999). Effects of exogenous methyl jasmonate in elicited anthocyanin-producing cell cultures of ohelo (Vaccinium pahalae). In Vitro Cell. Dev. Biol. Plant, 35: 106-113.

Fasoyiro, S.B., Ashyaye, O.A., Adeola, A. and Samuel, F.O. (2005). Chemical and storability of fruit flavoured (Hibiscus sabdariffa) drinks. World J. Agric. Sci., 1:165168.

Ghatas, Y.A.A. and Mohamed, Y.F.Y. (2018). Influence of mineral, micronutrients and lithovit on growth, oil productivity and volatile oil constituents of Cymbopo- 
gon citruts L. plants: Middle East J. Agric. Res., 7:162-174.

Gomaa A.O., Youssef, A.S.M., Mohamed, Y.F.Y. and M.S.A. AbdAllah (2018): Effect of some fertilization treatments on growth, productivity and chemical constituents of roselle (Hibiscus sabdariffa L.) plants. Scientific J. Flowers \& Ornamental Plants, 5(2):171-193.

Goos, R.J., Johnson, B., Jackson, G. and Hargrove, G. (2004). Greenhouse evaluation of controlled-release iron fertilizers for soybean. J. Plant Nutr., 27: 43-55.

Goos, R.J. and Johnson, B.E. (2000). A comparison of three methods for reducing iron deficiency chlorosis in soybean. Agron. J., 92: 11351139.

Guo, W., Nazim, H., Liang, Z. and Yang, D. (2016). Magnesium deficiency in plants: An urgent problem. The Crop Journal, 4(2): 8391.

Harris, K.D., Vanajah, T. and Puvanitha, S. (2018). Effect of foliar application of Boron and Magnesium on growth and yield of green chilli (Capsicum annum L.). AGRIEAST: J. Agric. Sci., 12(1): 26-33.

Hatier, J.-H. B. and Gould, K.S. (2009). Anthocyanin Function in Vegetative Organs. In: Gould, K., Davies, K.M and Winefield, C. (Eds.), Anthocyanins, Biosynthesis, Functions, and Applications. SpringerVerlag New York, pp. 1-19.

Hussin, M.S., El-Sherbeny, S.E., ElSaeid, H.M. and Kandeel, M.M. (1991). Field experiments of foliar application with B-9 and Micronutrients on Hibiscus sabdariffa, L.: growth yield and hormonal content. J. Egypt Hort., 16(1): 59- 68.

Ibrahim, O.H.M., Abdul-Hafeez, E.Y., Abdel-Kader, A.A.S. (2016a). Assessment of two newly introduced parsley varieties for productivity and quality as affected by iron and magnesium foliar application under upper Egypt conditions. Assiut J. Agric. Sci., 47(1): 75- 88.

Ibrahim, O.H.M., Abdul-Hafeez, E.Y., Abdel-Kader, A.A.S. (2016b). Impact of climatic changes on safflower (Carthamus tinctorius L.) productivity: improving growth and carthamin pigment content by sowing date adaptation and micronutrients foliar application. J. Plant Production, Mansoura Univ., 7(1): 77- 84.

Jackson, M.L. (1973). Soil Chemical Analysis. Printice-Hall of India. Privat Limited, New Delhi, p. 498.

Kirby, R.H. (1963). Vegetable, Fibers Ed - by Prof. Nicholes, Pallman pp. 29-31. Inter-Science Publishe Inc. New York.

Kondo,T., Yoshida, K., Nakagawa, A., Kawai, T., Tamura, H. and Goto, T. (1992). Structural basis of bluecolour development in flower petals from Commelina communis. Nature, 358: 515-518.

Lee, J., Durst, R.W. and Wrolstad, R.E. (2005). Determination of total monomeric anthocyanin pigment content of fruit juices, beverages, natural colorants, and wines by the $\mathrm{pH}$ differential method: Collaborative study. J. AOAC Int., 88: 1269-1278.

Malakouti, M.J. and Tehrani, M.H. (1999). Effect of micronutrients in yield increase and improvement of crops quality. Tarbiat Modarres University Press

Marschner, H. (2012). Mineral Nutrition of Higher Plants. $3^{\text {rd }}$ ed., Academic press, Elsevier Ltd., p. 672.

Nakhumicha Muriithi, A., Wamocho, L.S. and Njoroge, J.B.M. (2009). Effect of $\mathrm{pH}$ and magnesium on colour development and anthocyanin accumulation in tuberose flo- 
rets. African Crop Science Conference Proceedings, Afr. Crop Sci. Soc., 9: $227-234$.

Nissim-Levi, A., Ovadia, R., Forer, I. and Oren-Shamir, M. (2007). Increased anthocyanin accumulation in ornamental plants due to magnesium treatment, The Journal of Hort. Sci. and Biotechnol., 82(3): 481-487.

Ram, R.A. and Bose, T.K. (2000). Effect of foliar application of magnesium and micronutrients on growth, yield and fruit quality of mandarin orange (Citrus reticulata Blanco). Ind. J. Hort., 57(3): 215-220.

Rathore, D.S. and Tomar, S.S. (1990). Effect of sulphur and nitrogen on seed yield and nitrogen uptake by mustard. Ind. J. Agron., 35(4): 361-363.

Said-Al Ahl, H.A.H. and Omer, E.A. (2009). Effect of spraying with zinc and / or iron on growth and chemical composition of coriander (Coriandrum sativum L.) harvested at three stages of development. J. Medicinal Food Plants, 1(2): 3046.

Shaked-Sachray, L., Weiss, D., Reuveni, M., Nissim-Levi, A. and OrenShamir, M. (2002). Increased anthocyanin accumulation in aster flowers at elevated temperatures due to magnesium treatment. Physiol. Plant., 114: 559-565.

Shaul, O., Hilgemann, D.W., deAlmeida-Engler, J. Van Montagu, M., Inze, D. and Galili, G. (1999). Cloning and characterization of a novel $\mathrm{Mg}^{2+} / \mathrm{H}^{1+}$ exchanger. Embo. J., 18: 3973-3980.

Shi, P., Li, B., Chen, H., Song, C., Meng, J., Xi, Z. and Zhang, Z. (2017). Iron supply affects anthocyanin content and related gene expression in berries of Vitis vinifera cv. Cabernet Sauvignon Molecules, 22 (2): 283.
Snedecor, G.W. and Cochran, W.G. (1989). Statistical Methods. $8^{\text {th }}$ ed., Iowa State University Press, Ames. Iowa, USA.

Steel, R.G. and Torrie, T.H. (1982). Principles and Procedures of Statistics. McGraw-Hill International Book Company, $3^{\text {rd }}$ ed., London.

Street, H.E. and H. Opik (1976). The Physiology of Flowering Plants. $2^{\text {nd }}$ ed., English Soc. Pub., William Clowes \& Sons, Ltd., London, UK.

Takeda, K. (2006). Blue metal complex pigments involved in blue flower colour. Proceedings of the Japan Academy, Series B. Physical and Biological Sciences, 82: 142-154.

Takeda, K., Yanagisawa, M., Kifune, T., Kinoshita, T. and Timberlake, C. F. (1994). A blue pigment complex in flowers of Salvia patens. Phytochemistry, 29, 1089-1091.

Tariq, A., Gill Rahmatullah, M.A. and Sabir, M. (2004). Mineral nutrition of fruit trees. Proceeding of. PlantNutrition Management for Horticultural Crops under Water-Stress Conditions, Agriculture Research Institute, Sariab, Quetta, pp. 28-33.

Tato, L., De Nisi, P., Donnini, S. and Zocchi, G. (2013). Low iron availability and phenolic metabolism in a wild plant species (Parietaria judaica L.). Plant Physiol. Biochem., 72: 145-153.

Upadhyay, R.K. and Patra, D.D. (2011). Influence of secondary plant nutrients $(\mathrm{Ca}$ and $\mathrm{Mg})$ on growth and yield of chamomile (Matricaria recutita L.). Asian J. Crop Sci., 3: 151-157.

Venkataramana, P. (2012). Magnesium and boron nutrition of black pepper (Piper nigrum L.). In laterite soils. M.Sc. Thesis. Fc. Agric., Kerala Agriculture University, India.

Walker, D.R. amd Fisher, E.G. (1957). The use of chelated magnesium 
and magnesium sulfate in correcting magnesium deficiency in apple orchards. Proc. Amer. Soc. Hort. Sci., 70: 15-20.

Waskela, R. S., Kanpure, R. N., Kumawat, B. R. and Kachouli, B. K. (2013). Effect of foliar spray of micronutrients on growth, yield and quality of Guava (Psidium guajava L.) cv. Dharidar Int. J. Res. Agric. Sci., 9(2): 551- 556.

Wiersma, J.V. (2005). High rates of FeEDDHA and seed iron concentration suggest partial solutions to iron deficiency in soybean. Agron. J., 97: 924-934. 


\section{الماغنسيوم والحديد المخلبي يحسن إنتاجية الكركديه ومحتوى الكؤؤس من الأثثوثياتينات}

عمر حسني محمد إبراهيم

قسم نباتات الزينة وتتسيق الحدائق، كلية الزر اعة ، جمدي إميرة أسيوط

الملخص

أجريت هذه الدراسة لتحديد فاعلية الرش الورقى (تثلاث مرات) بكل من الماغنسيوم

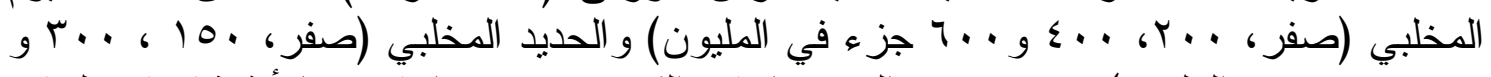

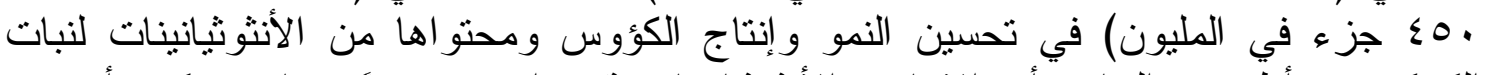

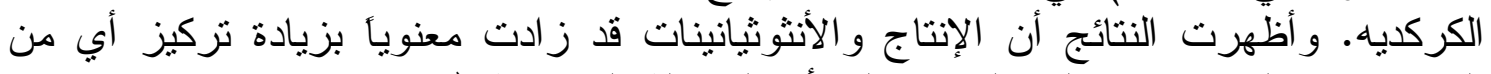

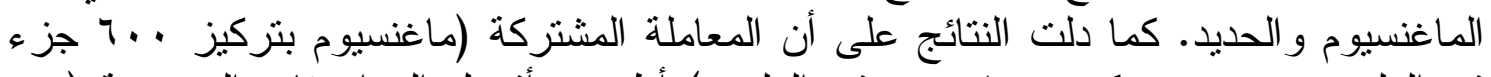

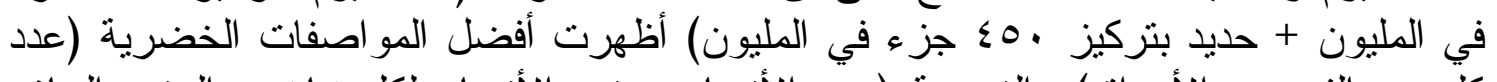

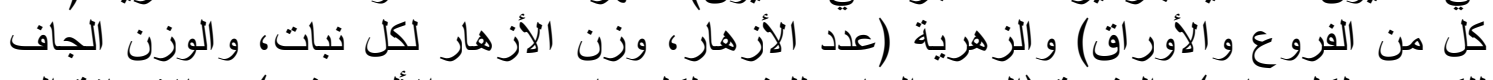

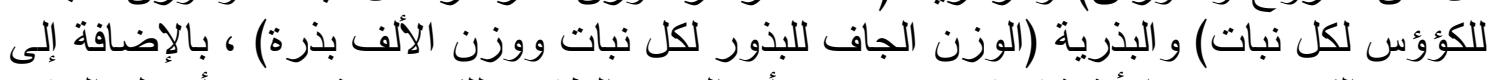

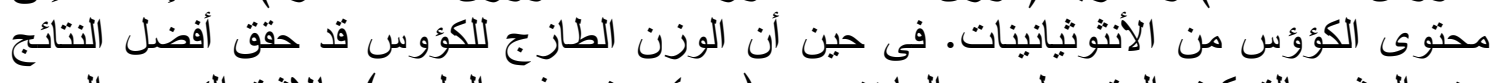

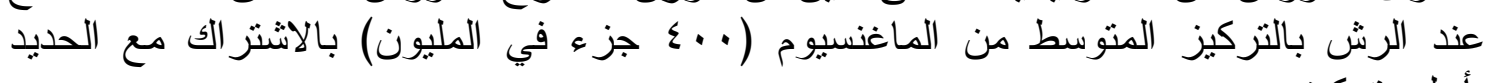
بأعلى تركيز • 